\title{
Micro-environment characteristics and microbial communities in activated sludge flocs of different particle size
}

\author{
Yunping Han, Junxin Liu*, Xuesong Guo, Lin Li \\ Research Center for Eco-Environmental Sciences, Chinese Academy of Sciences, Beijing 100085, China
}

\section{H I G H L I G H T S}

- Microelectrodes and molecular culture-independent techniques were applied.

- The micro-environment and bacteria in flocs with different size were detected.

- The DO, $\mathrm{NH}_{4}{ }^{+}$and $\mathrm{NO}_{3}{ }^{-}$concentration were distinct in flocs of different size.

- The bacterial population was closely related to the micro-environment in flocs.

\section{A R T I C L E I N F O}

\section{Article history:}

Received 6 May 2012

Received in revised form 27 July 2012

Accepted 2 August 2012

Available online 9 August 2012

\section{Keywords:}

Micro-environment

Microbial community

Microelectrodes

Fluorescence in situ hybridization

Activated sludge flocs

\begin{abstract}
A B S T R A C T
Microorganisms in activated sludge flocs (ASF) play important roles in the wastewater treatment process. However, the interplay between micro-environmental variation and microbial responses within ASF is poorly understood. In this study, microelectrodes and molecular culture-independent techniques were applied to detect the internal environment, microbial composition, and distribution in flocs with different particle size. Results showed dissolved oxygen (DO) concentrations within the center of the flocs were less than at the surface, and the DO concentration distributions were distinct in flocs of different particle size. With floc particle size increasing from 100 to $250 \mu \mathrm{m}$, the DO concentrations in the floc centers decreased $10-55 \%$, respectively, while no distinct change was observed in flocs of less than $100 \mu \mathrm{m}$. Similar phenomenon occurred for the distributions of $\mathrm{NH}_{4}{ }^{+}$and $\mathrm{NO}_{3}{ }^{-}$in flocs. Microbial structure indicated bacterial compositions and distributions were heterogeneous and responded to micro-environment variation in flocs of different particle size.
\end{abstract}

(c) 2012 Elsevier Ltd. All rights reserved.

\section{Introduction}

Activated sludge treatment of wastewater is one of the most important biotechnological processes in a wastewater treatment plant (WWTP). Generally, activated sludge flocs (ASF) are in the form of aggregates of microorganisms, suspended solids, and extracellular polymers (Jin et al., 2004). Removal of pollutants from wastewater mainly depends on the microbial composition and activity of activated sludge (Nadarajah et al., 2007; Pholchan et al., 2010; Wells et al., 2011). Thus flocs as microbiological units play an essential role in the operation of WWTPs. Better understanding the characteristics of inter-floc bacterial communities will help clarify the processes of pollutant biodegradation.

Previous research has shown that bacterial distribution in flocs is heterogeneous. For example, the distribution of ammoniaoxidizing bacteria (AOB) and nitrite-oxidizing bacteria (NOB) was

\footnotetext{
* Corresponding author. Tel./fax: +86 1062849133.

E-mail address: jxliu@rcees.ac.cn (J. Liu).
}

observed to be stratified in activated sludge by fluorescence in situ hybridization (FISH) (Schramm et al., 1999). Efforts have been made to link the relationship between the structure and function of microbial systems inside activated sludge flocs by using mathematical modeling, which show that microbial distribution is related to their resident environment inside activated sludge (Martins et al., 2004).

In addition to the model simulation, the ASF micro-environment has also been directly investigated. With the rapid development of microelectrode techniques in recent years, it was now possible to detect the inner characteristics of micro spaces, such as biofilms and granules (Yu and Bishop, 2001; Li and Bishop, 2002; Chu and Lee, 2004; Kishida et al., 2006; Shanahan and Semmens, 2006). Microelectrodes had been applied to detect the micro-environment in activated sludge aggregates. The $\mathrm{pH}$, oxidation-reduction potential (ORP), DO, $\mathrm{NH}_{4}{ }^{+}$, and $\mathrm{NO}_{3}{ }^{-}$concentrations were shown to decrease from the surface to the center of activated sludge aggregates with particle size of more than $1000 \mu \mathrm{m}$ (Li and Bishop, 2003, 2004; Satoh et al., 2003; Wang et al., 2011). Analysis of the DO diffusion in a single floc with $600 \mu \mathrm{m}$ sized particles was conducted 
Table 1

Concentration and removed rates of main pollutants in the investigated reactor ${ }^{\mathrm{a}}$.

\begin{tabular}{lccclcc}
\hline & $\mathrm{COD}$ & $\mathrm{BOD}_{5}$ & $\mathrm{NH}_{4}{ }^{+}-\mathrm{N}$ & $\mathrm{TN}$ & $\mathrm{TP}$ & $\mathrm{SS}$ \\
\hline Inffluent $(\mathrm{mg} / \mathrm{L})$ & 435 & 202 & 36.11 & 46.37 & 8.35 & 281 \\
Effluent $(\mathrm{mg} / \mathrm{L})$ & 37.2 & 9.2 & 2.63 & 14.56 & 4.76 & 24.9 \\
Removal rate (\%) & 91.4 & 95.4 & 92.7 & 68.6 & 43.0 & 90.7 \\
\hline
\end{tabular}

a See abbreviations in Section 2.1 .

using microelectrodes, which showed that DO concentration gradually decreased with depth of detection from the surface to the center of activated sludge (Tsai et al., 2008). Most activated sludge flocs have a diameter in the range of $68-183 \mu \mathrm{m}$ in a real WWTP (Schmid et al., 2003). For practical purposes, it is necessary to explore the characteristics and interplay of the micro-environment and microbial community in flocs with the same particle size as those in wastewater treatment processes, which will provide a theoretical foundation for the optimization of WWTP performance.

In this study, flocs from a real WWTP were divided into five levels according to their particle sizes. Four different microelectrodes were applied to assay the concentrations of $\mathrm{DO}, \mathrm{pH}, \mathrm{NH}_{4}{ }^{+}-$ $\mathrm{N}$, and $\mathrm{NO}_{3}{ }^{-}-\mathrm{N}$ in the activated sludge flocs. The corresponding bacterial communities in flocs were determined by molecular biological techniques. We aimed to analyze the characteristics of the ASF micro-environment with different particle size, and to explore the relationship between the micro-environment and bacterial community structure in flocs.

\section{Origin of activated sludge and methods}

\subsection{Activated sludge and classification of floc particles}

Activated sludge was taken from the outer channel of an Orbal oxidation ditch at a municipal wastewater treatment plant in Beijing, China. In this biological treatment unit, the sludge loading rate (SLR), sludge residence time (SRT), and the mixed liquor suspended solid (MLSS) were $0.13 \mathrm{kgBOD}_{5} / \mathrm{kgMLSS}^{\mathrm{d}}, 12 \mathrm{~d}$, and $3015 \mathrm{mg} / \mathrm{L}$, respectively. The average DO concentration was $0.6 \mathrm{mg} / \mathrm{L}$. Chemical oxygen demand (COD) was measured by a multi-function reactor (DR2800, Euro Tech) and portable spectrophotometers (DR2800, Hach). Ammonium nitrogen $\left(\mathrm{NH}^{+}-\mathrm{N}\right)$, total nitrogen (TN), total phosphorus(TP), biological oxygen demand
$\left(\mathrm{BOD}_{5}\right)$, and suspended substances (SS) were analyzed according to the standard methods (CEPB, 2004). The biological nutrient removal is listed in Table 1.

Particle size of the activated sludge was measured on-site by a portable laser particle analyzer (LISST-PORTABLE). As shown in Fig. 1, the distributions of floc size were normal. Flocs with particle size in the range of $0-250 \mu \mathrm{m}$ formed the major part of activated sludge. To analyze the micro-environmental characteristics in flocs of different size, the flocs were divided into five levels (L1-L5) based on the distribution of floc size. Their corresponding particle sizes were $<61 \mu \mathrm{m}$ for $\mathrm{L} 1,61-96 \mu \mathrm{m}$ for $\mathrm{L} 2,97-160 \mu \mathrm{m}$ for $\mathrm{L} 3$, $161-250 \mu \mathrm{m}$ for $\mathrm{L} 4$, and $>250 \mu \mathrm{m}$ for $\mathrm{L} 5$. Flocs with particle size below $250 \mu \mathrm{m}$ were investigated in this study as they dominated in flocs.

\subsection{Microelectrodes analysis}

Microelectrodes (Unisense Piocammeter PA2000, Denmark) were used to measure $\mathrm{DO}, \mathrm{pH}, \mathrm{NH}_{4}{ }^{+}-\mathrm{N}$, and $\mathrm{NO}_{3}{ }^{-}-\mathrm{N}$ in flocs of different size. The tip diameters of $\mathrm{DO}$ and $\mathrm{pH}$ microelectrodes were $10 \mu \mathrm{m}$, and the tip diameters of $\mathrm{NH}_{4}{ }^{+}-\mathrm{N}$ and $\mathrm{NO}_{3}{ }^{-}-\mathrm{N}$ microelectrodes were $20 \mu \mathrm{m}$. The measurement was executed in an upflow chamber filled with water (see the influent in Table 1) from the same WWTP. The DO concentration in the chamber was set to $0.7-0.8 \mathrm{mg} / \mathrm{L}$ in order that the ASF was at a similar state in the WWTP. In order to avoid the change of the floc shape, $200 \mu \mathrm{lmix}-$ ture including ASF with the similar size was taken to measure for each parameter. During the measurement, the ASF was stabilized using nylon nets to keep the suspended floc particles stationary. The microelectrodes were controlled to penetrate the flocs of each particle size by a Faraday cage. The step of detection was $25 \mu \mathrm{m}$. The micro-environment in flocs with the same range of particle size was detected three times, and the average was adopted.

\subsection{Molecular analysis}

\subsubsection{Polymerase chain reaction-denaturing gradient gel} electrophoresis (PCR-DGGE) and phylogenetic analysis

According to the principle of DGGE, total DNAs with the same length but different sequences can be separated. Each band corresponds approximately to a dominant microbial community member, with more bands suggesting higher diversity (Hesham et al., 2011). Taking respectively $200 \mu \mathrm{l}$ activated sludge flocs in the range

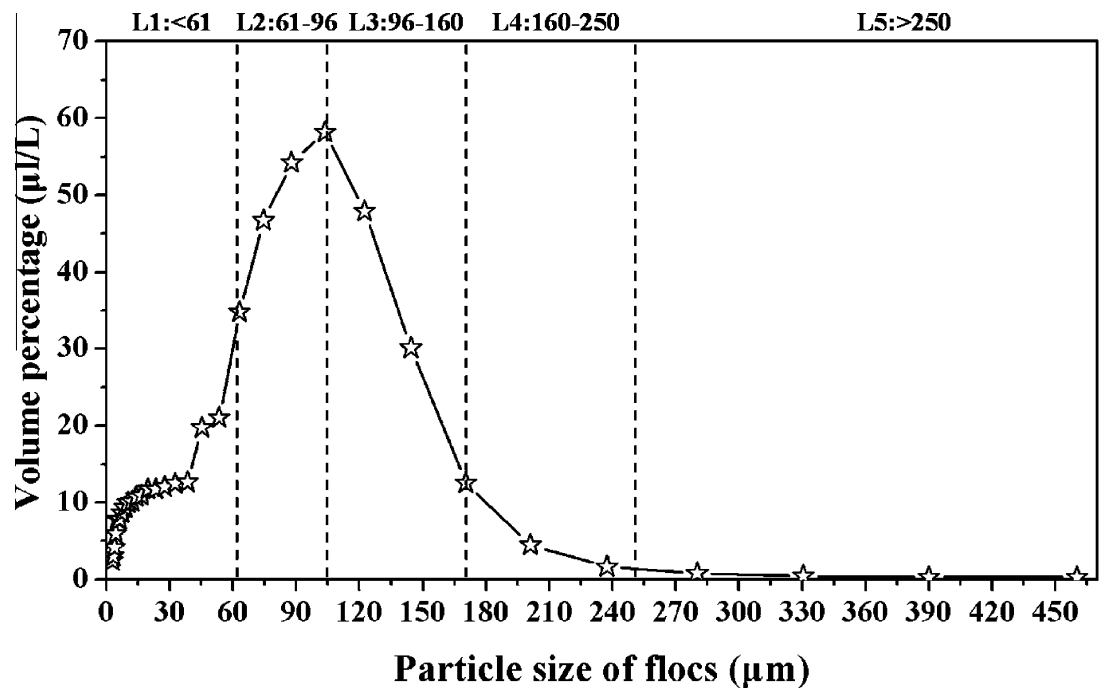

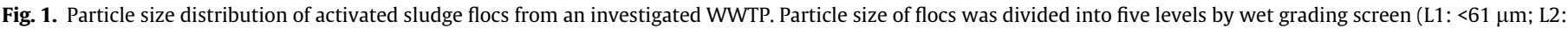

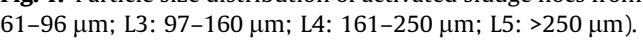


Table 2

List of 16S rRNA gene-targeted oligonucleotide probes used (Satoh et al., 2003; Gieseke et al., 2001).

\begin{tabular}{|c|c|c|c|c|}
\hline Probes & $\begin{array}{l}\text { Fluorescent } \\
\text { label }\end{array}$ & Sequence $\left(5^{\prime}-3^{\prime}\right)$ & $\mathrm{FA}(\%)^{\mathrm{a}}$ & Specificity \\
\hline Nit3 & FITC & CCTGTGCTCCATGCTCCG & 40 & $\begin{array}{l}\text { Nitrobacter } \\
\text { spp. }\end{array}$ \\
\hline Ntspa662 & FITC & GGAATTCCGCGCTCCTCT & 40 & $\begin{array}{l}\text { Genus } \\
\text { Nitrospira }\end{array}$ \\
\hline Nrs1156 & FITC & CCCGTTCTCCTGGGCAGT & 30 & $\begin{array}{l}\text { Genus } \\
\text { Nitrospira }\end{array}$ \\
\hline Nso190 & Cy5 & CGATCCСCTGCTTTTCTCC & 55 & $\begin{array}{l}\text { Ammonium } \\
\text { oxidizing } \beta \text { - } \\
\text { Proteobacteria }\end{array}$ \\
\hline Nso1225 & Cy5 & CGCGATTGTATTACGTGTGA & 35 & $\begin{array}{l}\text { Ammonium } \\
\text { oxidizing } \beta- \\
\text { Proteobacteria }\end{array}$ \\
\hline
\end{tabular}

a formamide concentration.

of different particle size for preparation of total DNA extracts were harvested by centrifugation $\left(4^{\circ} \mathrm{C}, 10 \mathrm{~min}, 12000 \mathrm{r} / \mathrm{min}\right)$ and then suspended in a $200 \mu \mathrm{l}(0.01 \mathrm{M})$ potassium phosphate buffer $(\mathrm{pH}$ 7.2).The isolation of total DNA was accomplished with Magnetic System-16 (TanBead, Taiwan). Primers F357GC and R518 were used to amplify the segment of eubacterial 16S rDNA (Gao et al., 2011). The PCR products generated from each sample were separated on an $8 \%$ acrylamide gel with a linear denaturant gradient increasing from $30 \%$ to $60 \%$ at $60{ }^{\circ} \mathrm{C}$ and $70 \mathrm{~V}$ for $960 \mathrm{~min}$. The digital images were captured by a Fluor-S Multilmager (Bio-Rad, USA) and analyzed with Quantity One Software (Bio-Rad, USA). The bacterial diversity was estimated from the intensity and number of bands using the Shannon index (H) (Ding et al., 2008). Prominent DGGE bands were excised for sequencing using ABI 3730XL capillary sequencers
(Biomed, Beijing, China). Homology of sequence searches were conducted using the GenBank server of the National Centre for Bio-technology Information (NCBI) and the BLAST algorithm.

\subsubsection{Fish}

Activated sludge floc in the range of different particle size was respectively fixed by $4 \%$ paraformaldehyde at $4{ }^{\circ} \mathrm{C}$ for $12 \mathrm{~h}$ for the FISH experiments. The fixed floc was washed three times with phosphate-buffered saline ( $\mathrm{pH}: 7.2$ ), and suspended in phosphatebuffered saline. $10 \mu \mathrm{l}$ suspension including ASF was spotted on gelatin-coated glass slides in the form of layer. After air-dried, the floc was consecutively dehydrated in $50 \%, 80 \%$, and $100 \%$ ethanol. A hybridization solution containing $5 \mathrm{ng} / \mu \mathrm{l}$ of probe was applied to the slide. In situ hybridization was performed at $46^{\circ} \mathrm{C}$ for $3 \mathrm{~h}$. Excess probes were washed at $48^{\circ} \mathrm{C}$ for $15 \mathrm{~min}$ with washing buffer. Biomass on the slide was stained with DAPI solution. The images of FISH were captured by confocal lasers scanning microscopy (CLSM) and analyzed with LAS AF Lit software. Lists of oligonucleotide probes applied and respective target bacteria are shown in Table 2 .

\section{Results}

3.1. Micro-environmental characteristics in ASF with different particle size

Type chemical profiles in activated sludge flocs of different particle size were detected by microelectrode technique to characterize the micro-environment of the flocs. A gradual change in DO and concentration of $\mathrm{NH}_{4}{ }^{+}$and $\mathrm{NO}_{3}{ }^{-}$occurred in flocs with different particle size (Figs. 2 and 3 ). The $\mathrm{pH}$ value remained relatively constant at 7.0-7.2 in all ASF of tested particle sizes.
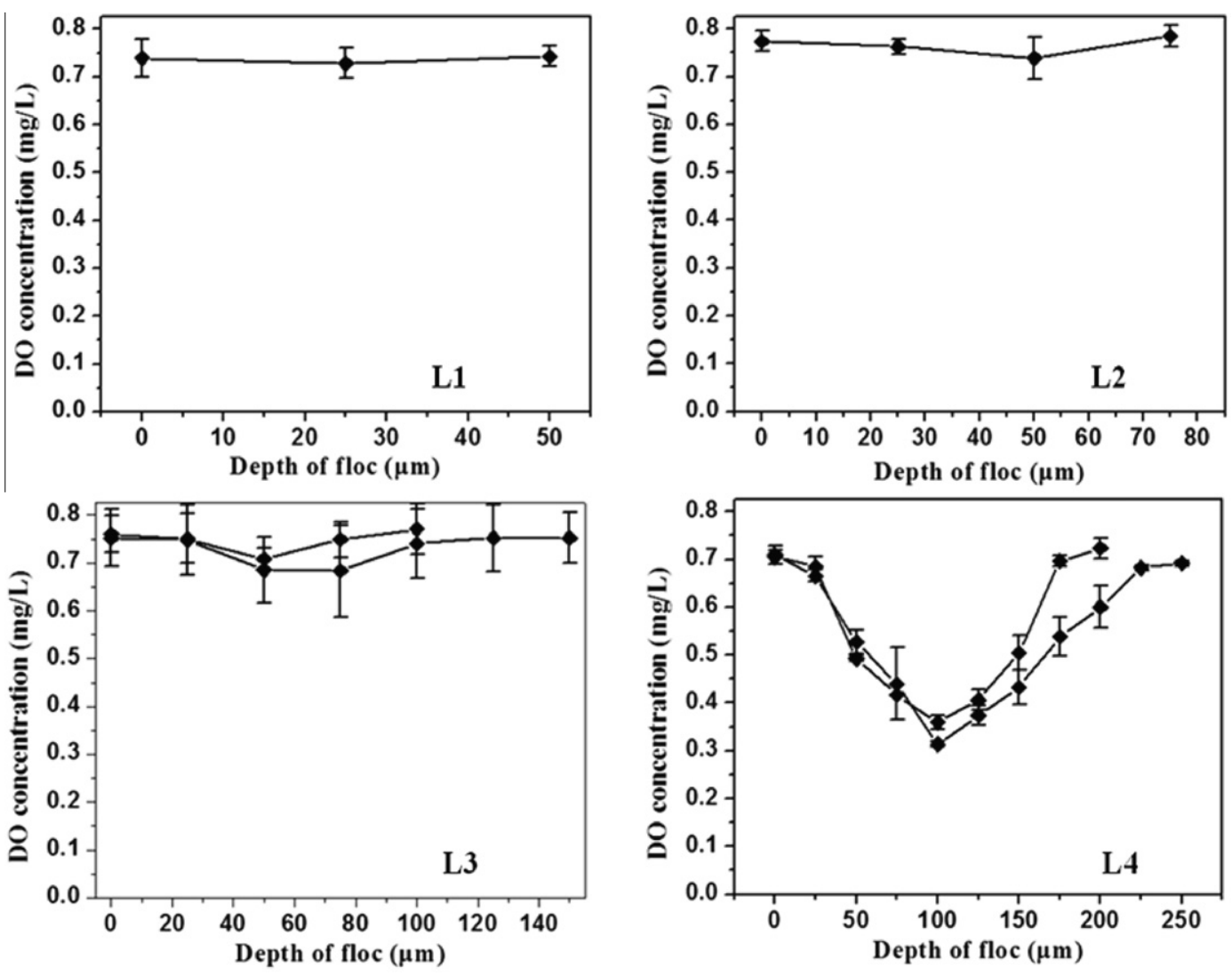

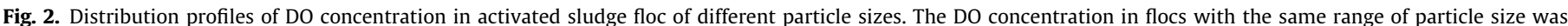
detected three times. 

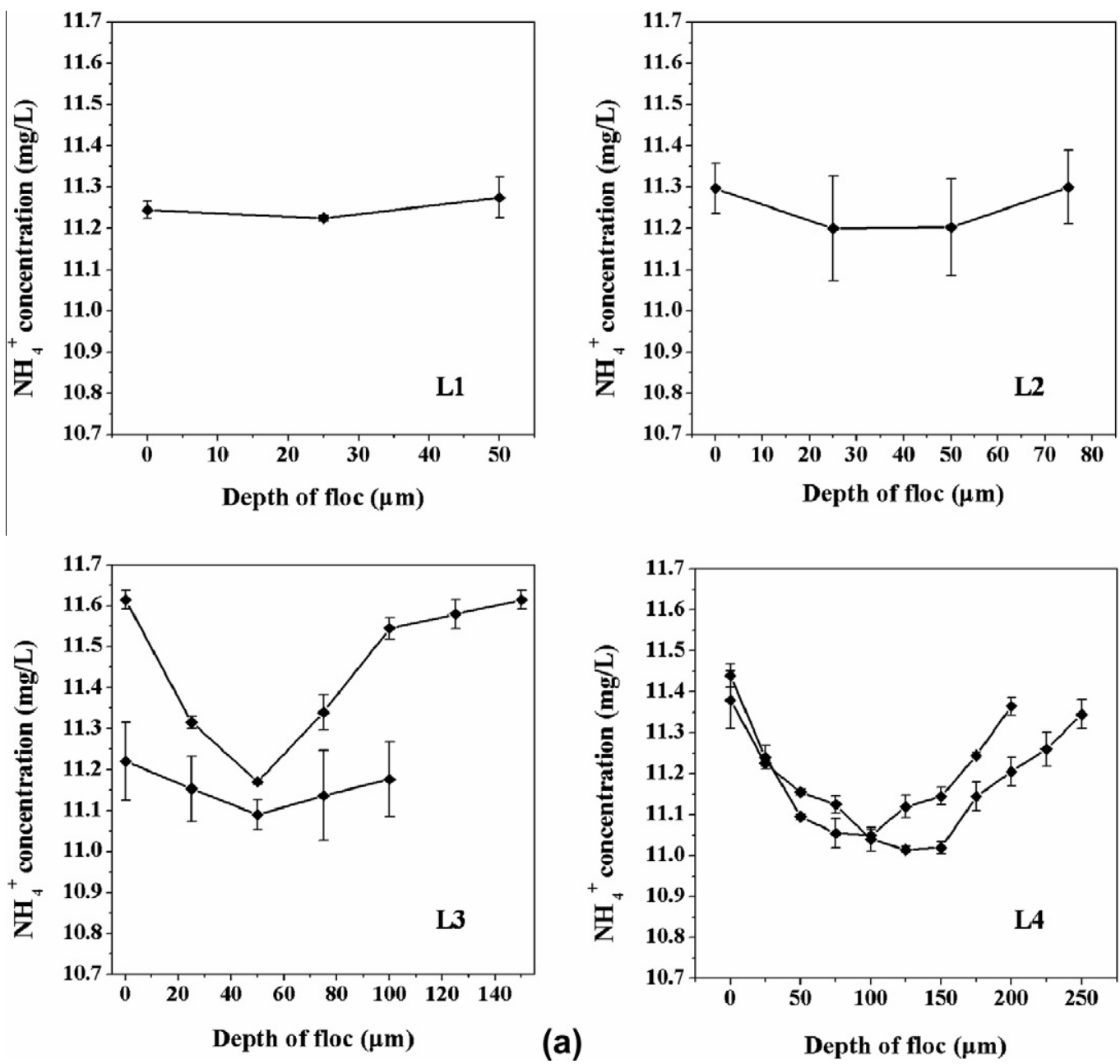

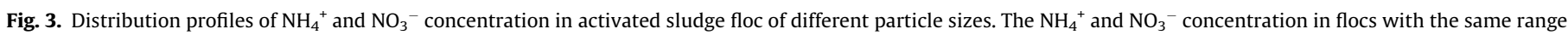
of particle size was detected three times.

For L1 shown in Fig. 2 and Fig. 3, the distribution of DO, $\mathrm{NH}_{4}{ }^{+}$, and $\mathrm{NO}_{3}{ }^{-}$penetrated the whole floc when the particle size was $50 \mu \mathrm{m}$. Minor changes (from 0.74 to $0.73 \mathrm{mg} / \mathrm{L}$ ) in DO concentration occurred from the floc surface to the core in L1. From the floc surface to its core, the concentrations of $\mathrm{NH}_{4}{ }^{+}$and $\mathrm{NO}_{3}{ }^{-}$decreased from 11.28 to $11.23 \mathrm{mg} / \mathrm{L}$ and from 0.23 to $0.21 \mathrm{mg} / \mathrm{L}$, respectively. The decrement rates were only $0.4 \%$ and $8.7 \%$, respectively. The same phenomenon was observed in flocs of $75 \mu \mathrm{m}$ (L2 in Fig. 2 and Fig. 3). The $\mathrm{DO}, \mathrm{NH}_{4}{ }^{+}$, and $\mathrm{NO}_{3}{ }^{-}$concentrations in the floc core dropped gradually with increasing particle size. This decrement in floc core presented as a more obvious trend in L3. The DO concentration decreased from $0.72 \mathrm{mg} / \mathrm{L}$ (surface) to $0.68 \mathrm{mg} / \mathrm{L}$ (core) in the flocs with particle size of $100 \mu \mathrm{m}$. The corresponding $\mathrm{NH}_{4}{ }^{+}$and $\mathrm{NO}_{3}{ }^{-}$concentrations reduced from 11.42 and $0.78 \mathrm{mg} / \mathrm{L}$ on the surface to 11.12 and $0.59 \mathrm{mg} / \mathrm{L}$ in the core, respectively (L3 in Fig. 2 and Fig. 3). When the floc particle size increased to $150 \mu \mathrm{m}$, the decreasing chemical concentration trend in the floc core was more obvious. The DO, $\mathrm{NH}_{4}{ }^{+}$, and $\mathrm{NO}_{3}{ }^{-}$concentration from the surface to the core decreased $14.1 \%, 3.4 \%$, and $76.0 \%$, respectively. The most dramatic change in ASF chemical concentration was shown for the particle size range of $\mathrm{L} 4$ (L4 in Figs. 2 and 3). The $\mathrm{DO}, \mathrm{NH}_{4}{ }^{+}$, and $\mathrm{NO}_{3}{ }^{-}$concentrations in the $200 \mu \mathrm{m}$ floc core were $0.36,11.05$, and $0.13 \mathrm{mg} / \mathrm{L}$, respectively. A similarly sharp variation was exhibited in flocs $250 \mu \mathrm{m}$ in size, with decrement rates for $\mathrm{DO}, \mathrm{NH}_{4}{ }^{+}$and $\mathrm{NO}_{3}{ }^{-}$concentration reaching $54.9 \%, 3.4 \%$, and $90.8 \%$, respectively. Our results suggested that the chemical concentrations in floc cores gradually decreased with the increase in floc particle size.

\subsection{Microbial communities in flocs of each particle size level}

The bacterial communities of flocs of each particle size level were analyzed by DGGE of PCR-amplified 16S rRNA gene fragments (Fig. 4). The bacterial diversities in lanes of L3 and L4 were richer than that in lanes of L1 and L2 (Fig. 4). In addition, the bacterial community in flocs felled into ranges of L1 and L2 was similar, as were the bacterial structure in L3 and L4. These data verified that bacterial diversity in activated sludge flocs with particle sizes of more than $100 \mu \mathrm{m}$ (e.g. L3 and L4) was richer than those with the particle size of less than $100 \mu \mathrm{m}$ (e.g. L1 and L2).

Twenty-one (B1-B21 shown in Fig. 4) and nine (S1-S9 shown in Fig. 4) dominant bands were obtained for sequence analysis from L3-L4 and L2, respectively. Each sequence was submitted to a BLAST search, and a phylogenetic tree was constructed from sequences in this study and their closest relative sequences (Table 3 ).

As shown in Table 3, bacteria affiliated with Proteobacteria, Bacteroidetes and Firmicutes were abundant in all activated sludge flocs of each particle size level. Six species, involving uncultured Bacillus licheniformis, uncultured Bacillus sp., uncultured Clostridiaceae bacterium and unclassified bacterium, formed the phylum of Firmicutes in L3 and L4. Bacteria of Proteobacteria in flocs of these two levels were subgrouped into $\alpha$-, $\beta$-, and $\gamma$-Proteobacteria. The bacteria affiliated with Bacteroidetes were richest in L3 and L4, including three species of uncultured Bacteroidetes bacteria and five species of unclassified bacteria (Table 3). Compared to that in L3 and L4, less bacterial diversity was found in $\mathrm{L} 1$ and $\mathrm{L} 2$. The $\alpha$-Proteobacteria 

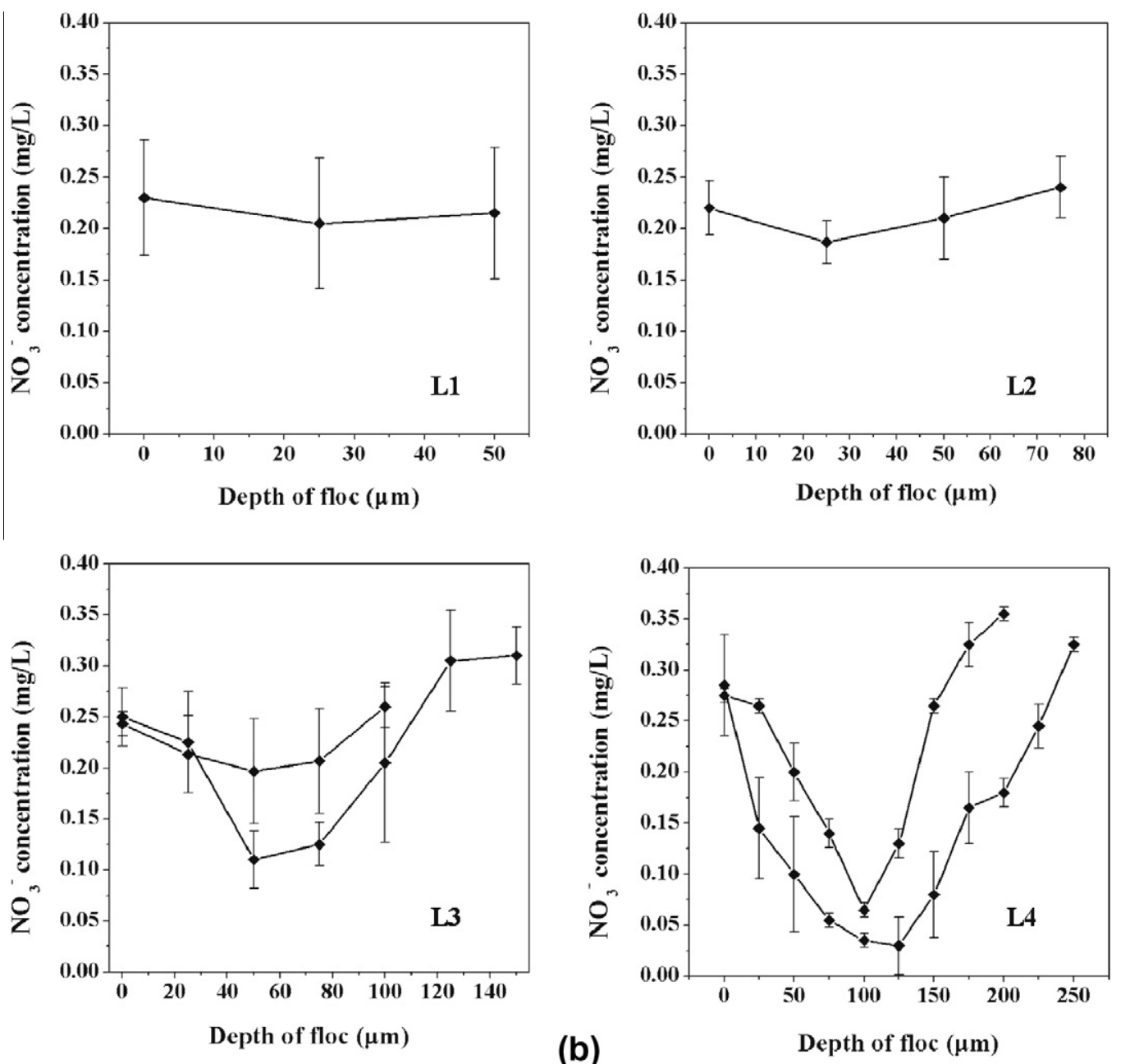

Fig. 3 (continued)

and $\gamma$-Proteobacteria as well as uncultured Bacillus licheniformis found in L3 and L4 were not detected in L1 or L2 (Table 3). All bacteria found in L1 and L2 were also found in L3 and L4. These results illustrated that bacterial diversity in flocs was richer with increasing floc particle size. There were more species of dominant bacteria in the larger flocs (L3 and L4) than in the smaller flocs (L1 and L2), and most dominant bacteria in the smaller flocs were also presented in the larger flocs.

\subsection{Distribution of functional bacteria in flocs of each particle size level}

The FISH technique was used to assay the distribution of functional microbiota in flocs of different particle size. Meanwhile, Quantitative data of each bacterial population in flocs can be obtained (Wagner et al., 1993; Juretschko et al., 2002) via combination CLSM and image analysis. The distribution and relative contents of ammonia-oxidizing bacteria (AOB) and nitriteoxidizing bacteria (NOB) in flocs of two particle size levels, L1 $(<61 \mu \mathrm{m})$ and $\mathrm{L} 3(97-160 \mu \mathrm{m})$, were detected and analyzed. The results showed in Supplementary Figure. Both AOB (show in yellow) and NOB (show in green) exhibited a clustered scattering on the surface of flocs with particle size of 97-160 $\mu \mathrm{m}$ (Supplementary Fig. a). The mean frame intensities of yellow and green showed that AOB and NOB gradually decreased with floc depth (Supplementary Fig. a). A sharp decrease in AOB and NOB was observed from 20 to $35 \mu \mathrm{m}$ below the floc surface, and AOB and NOB were not detected in the floc core. When the particle size of the floc was below $61 \mu \mathrm{m}$, both AOB and NOB were distributed evenly from the surface to the floc core, and their intensities remained consistent (Supplementary Fig. b). The mean frame intensities of yellow and green were almost the same from surface to core. With the increasing of floc size, the distribution of $A O B$ and NOB in the floc varied accordingly.

\section{Discussion}

Different micro-environmental characteristics and bacterial composition were found in flocs of different particle size. The results in Fig. 2 to Fig. 3 show the distribution of $\mathrm{DO}, \mathrm{NH}_{4}{ }^{+}$, and $\mathrm{NO}_{3}{ }^{-}$concentration in flocs with different particle size. A chemical heterogeneous structure was formed in larger flocs. In this study, the concentrations of $\mathrm{DO}, \mathrm{NH}_{4}{ }^{+}$and $\mathrm{NO}_{3}{ }^{-}$decreased obviously from surface to core in flocs with particle size over $100 \mu \mathrm{m}$ (L3 and L4). When the floc size was below $100 \mu \mathrm{m}$ (L1 and L2), the DO, $\mathrm{NH}_{4}^{+}$ and $\mathrm{NO}_{3}{ }^{-}$concentrations in the floc were relatively even. In flocs below $61 \mu \mathrm{m}$ in size (L1), the DO, $\mathrm{NH}_{4}{ }^{+}$and $\mathrm{NO}_{3}{ }^{-}$concentrations almost penetrated the whole floc.

Mass transfer efficiency is one of the key reasons for the formation of distinct micro-environments in different size flocs. Diffusion is considered the most important mechanism of solute transport through flocs and is generally described using effective diffusivity. Temperature, pressure, and medium composition, as well as floc characteristics such as dimension and shape, are crucial for the assessment of effective diffusivity. The imitation of micromorphology in a floc indicates that mass transfer resistance is 


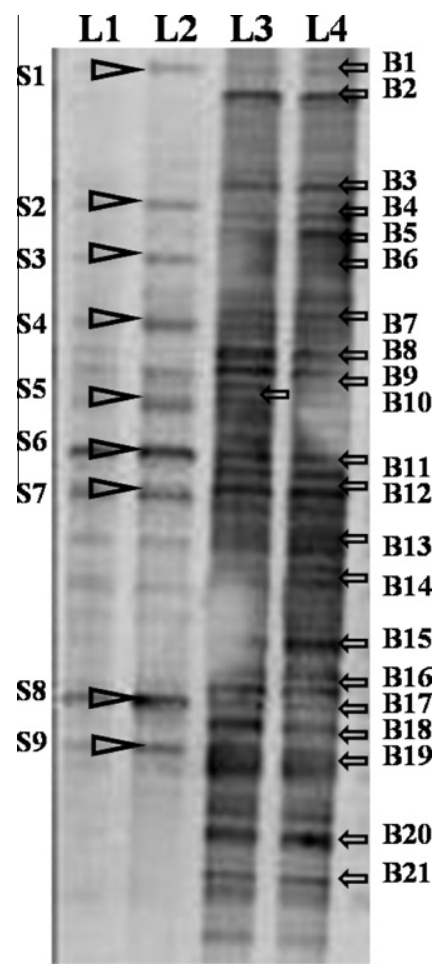

Fig. 4. DGGE profile of $P C R$ product derived from $16 S$ rDNA extracted from activated sludge floc (S1-S9 marks the dominant bands excised for sequencing from L1 and L2, and B1-B21 marks the dominant bands excised for sequencing from L3 and L4).

the main reason for chemical heterogeneous structure in flocs by modeling (Takacs and Fleit, 1995; Abbassi et al., 2000). The resistance of mass transfer increases and effective diffusivity declines with increasing floc size (Vicente et al., 1998). The increased size of flocs is the major contributor to total mass transfer resistance to oxygen (Chu et al., 2005; Ge et al., 2006). In this study, gradually declining concentrations of $\mathrm{DO}, \mathrm{NH}_{4}{ }^{+}$and $\mathrm{NO}_{3}{ }^{-}$were observed with increasing floc particle size. A potential reason was that mass transfers of $\mathrm{DO}, \mathrm{NH}_{4}$, and $\mathrm{NO}_{3}$ from the surface to the core were limited by floc particle size.

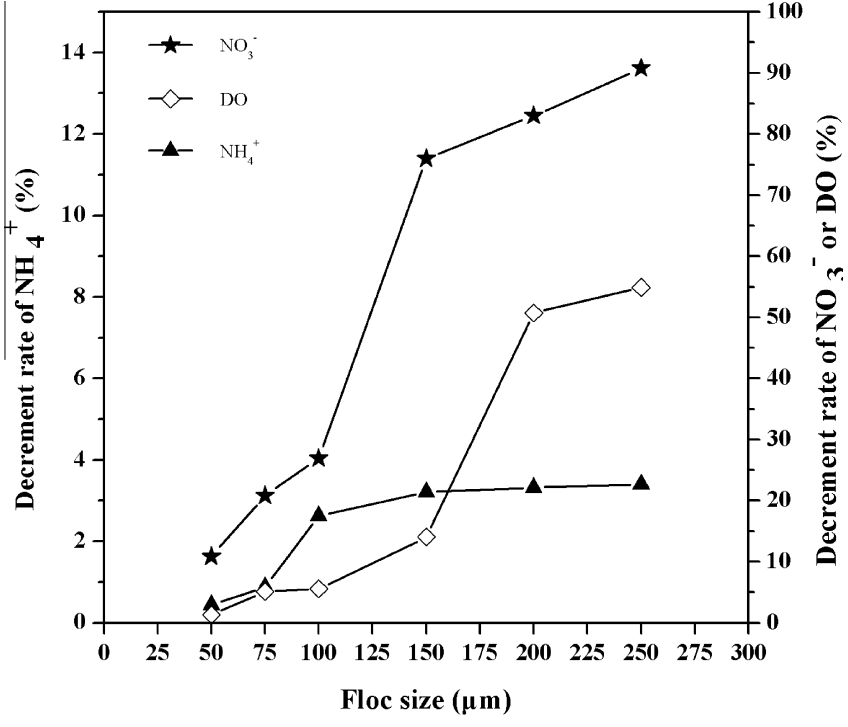

Fig. 5. Profile of $\mathrm{DO}, \mathrm{NH}_{4}{ }^{+}$and $\mathrm{NO}_{3}{ }^{-}$concentration decrement rate in activated sludge flocs of different particle size.

Bacterial consumption during biological processes may also explain the gradual decline of $\mathrm{DO}, \mathrm{NH}_{4}{ }^{+}$and $\mathrm{NO}_{3}{ }^{-}$in flocs. Aerobic biodegradation of pollutants is an important parameter in the consumption of oxygen in wastewater. Sharp depletion of DO concentration was observed in larger flocs due to the microorganisms' consumption of oxygen (L4 in this study). The decrement rate of $\mathrm{NH}_{4}{ }^{+}$concentration was lower than that of $\mathrm{DO}$ and $\mathrm{NO}_{3}{ }^{-}$(Fig. 5). Because the activated sludge flocs were collected from the outer channel of an Orbal oxidation ditch with priority to denitrification, low $\mathrm{NO}_{3}{ }^{-}$concentration was detected in this study. The decrement rate of $\mathrm{NO}_{3}{ }^{-}$concentration from surface to floc core sharply increased with increased floc particle size. Denitrification inside the flocs also likely influenced the decreasing $\mathrm{NO}_{3}{ }^{-}$concentration. The $\mathrm{NH}_{4}{ }^{+}$concentration was maintained at $11.00-11.70 \mathrm{mg} / \mathrm{L}$, indicating minimal $\mathrm{NH}_{4}{ }^{+}$consumption.

The biologically heterogeneous structure was also observed in larger sized flocs $(96-160 \mu \mathrm{m})$. The FISH images clearly demonstrated a gradient decline of $A O B$ and NOB from the surface to the core of larger flocs $(96-160 \mu \mathrm{m})$. Functional bacterial distribution

Table 3

Identification results for representatives of DGGE bands.

\begin{tabular}{|c|c|c|c|c|}
\hline \multirow[t]{2}{*}{ Phylogenetic group } & \multicolumn{2}{|l|}{ Bands } & \multirow[t]{2}{*}{ Closest relative in NCBI database } & \multirow[t]{2}{*}{ Similarity (\%) } \\
\hline & $\mathrm{L} 1, \mathrm{~L} 2$ & $\mathrm{~L} 3, \mathrm{~L} 4$ & & \\
\hline \multirow[t]{6}{*}{ Firmicutes } & S3 & B6 & Uncultured bacterium & 99 \\
\hline & S6 & B11 & Uncultured bacterium & 100 \\
\hline & S8 & B17 & Uncultured Bacillus sp. & 99 \\
\hline & S9 & B19 & Uncultured Clostridiaceae bacterium & 100 \\
\hline & & B8 & Uncultured bacterium & 99 \\
\hline & & B15 & Uncultured Bacillus licheniformis & 100 \\
\hline$\alpha$-Proteobacteria & & B3 & Uncultured Alphaproteobacterium & 99 \\
\hline \multirow[t]{2}{*}{$\gamma$-Proteobacteria } & & B13 & Uncultured Enhydrobacter sp. & 100 \\
\hline & & B18 & Uncultured bacterium & 100 \\
\hline \multirow{3}{*}{$\beta$-Proteobacteria } & S2 & B4 & Uncultured bacterium & 100 \\
\hline & S4 & B7 & Enrichment cultured bacterium & 100 \\
\hline & S7 & B12 & Uncultured bacterium & 97 \\
\hline \multirow[t]{8}{*}{ Bacteroidetes } & $\mathrm{S} 1$ & B1 & Uncultured Bacteroidetes & 100 \\
\hline & S5 & B10 & Uncultured bacterium & 100 \\
\hline & & B2 & Uncultured Bacteroidetes & 99 \\
\hline & & B5 & Uncultured Bacteroidetes & 100 \\
\hline & & B9 & Uncultured bacterium & 100 \\
\hline & & B14 & Uncultured bacterium & 100 \\
\hline & & B16 & Uncultured bacterium & 100 \\
\hline & & $\mathrm{B} 20$ & Uncultured bacterium & 99 \\
\hline Unclassified bacterium & & B21 & Uncultured bacterium & 100 \\
\hline
\end{tabular}


was closely related to the micro-environment formed in individual flocs with different particle sizes. It is well known that nitrifying bacteria are sensitive to environmental factors, such as oxygen concentration and substance concentration (Guo et al., 2009; Zeng et al., 2010; Chang et al., 2011). In larger flocs, more AOB and NOB were found in the surfaces where DO concentrations were high. When DO concentration decreased sharply in the floc core, AOB and NOB gradually decreased and then disappeared. Both AOB and NOB were found homogenously from surface to core in smaller flocs. These results indicated that variation of the micro-environment of flocs affected bacterial composition and distribution. The micro-environmental characteristics in a floc will influence the structure of the bacterial community.

Biological heterogeneous distribution will benefit the stable performance of biological treatment processes of WWTP. As shown in Fig. 1, the activated sludge in WWTP consisted of flocs with different particle size. Each size level presented a distinct micro-environment and bacterial structure. Therefore, construction of stable activated sludge flocs of different sizes will benefit the synchronous removal of many pollutants in WWTPs. Particle size of activated sludge flocs was influenced by the flocculation and scatter of each other (Biggs and Lant, 2002). Proper control of shear stress, oxygen quantity, and pollutant concentration in water will help establish micro-environmental characteristics and bacterial communities inside flocs to improve the performance of biological processes in WWTPs.

\section{Conclusion}

In a real WWTP, activated sludge flocs within a certain range of particle size (e.g. flocs less than $250 \mu \mathrm{m}$ ) played an important role in biological reaction processes. The heterogeneous trend of DO, $\mathrm{NH}_{4}{ }^{+}$and $\mathrm{NO}_{3}{ }^{-}$concentrations from surface to core in ASF was observed when the floc particle size was large $(>100 \mu \mathrm{m})$. These micro-environmental characteristics in different sized flocs affected the bacterial diversity and distribution of functional microbiota. Stability of activated sludge flocs of different sizes will benefit the synchronous removal of many pollutants in WWTPs.

\section{Acknowledgements}

The authors thank Dr. Watts for the English revision of this manuscript. This research was financially supported by the National Natural Science Foundation of China (Nos. 50921064 and 51138009).

\section{Appendix A. Supplementary data}

Supplementary data associated with this article can be found, in the online version, at http://dx.doi.org/10.1016/j.biortech.2012.08. 008 .

\section{References}

Abbassi, B., Dullstein, A., Rabiger, N., 2000. Minimization of excess sludge production by increase of oxygen concentration in activated sludge flocs. Water Res. 34, $139-146$.

Biggs, C.A., Lant, P.A., 2002. Modelling activated sludge flocculation using population balances. Powder Technol. 124, 201-211.

CEPB (China Environmental Protection Bureau), 2004. Standard methods for examination of water and wastewater, fourth ed. Chinese Environmental Science Press, China.

Chang, C.Y., Tanong, K., Xu, J., Shon, H., 2011. Microbial community analysis of an aerobic nitrifying-denitrifying MBR treating ABS resin wastewater. Bioresour. Technol. 102, 5337-5344.

Chu, C.P., Lee, D.J., 2004. Structural analysis of sludge flocs. Adv. Powder Technol. 15, 515-532.
Chu, C.P., Tsai, D.G., Lee, D.J., Tay, J.H., 2005. Size-dependent anaerobic digestion rates of flocculated activated sludge: role of intrafloc mass transfer resistance. J. Environ. Manage. 76, 239-244.

Ding, Y., Wu, W.X., Han, Z.Y., Chen, Y.X., 2008. Correlation of reactor performance and bacterial community composition during the removal of trimethylamine in three-stage biofilters. Biochem. Eng. J. 38, 248-258.

Gao, M., Li, L., Liu, J.X., 2011. Simultaneous removal of hydrogen sulfide and toluene in a bioreactor: performance and characteristics of microbial community. J. Environ. Sci. 23, 353-359.

Ge, X.M., Zhang, L., Bai, F.W., 2006. Impacts of yeast floc size distributions on their observed rates for substrate uptake and product formation. Enzyme Microb. Technol. 39, 289-295.

Gieseke, A., Purkhold, U., Wagner, M., Amann, R., Schramm, A., 2001. Community structure and activity dynamics of nitrifying bacteria in a phosphate-removing biofilm. Appl. Environ. Microbiol. 67, 1351-1362.

Guo, J.H., Peng, Y.Z., Wang, S.Y., Zheng, Y.N., Huang, H.J., Zhongwei Wang, Z.W., 2009. Long-term effect of dissolved oxygen on partial nitrification performance and microbial community structure. Bioresour. Technol. 100, 2796-2802.

Hesham, A.E.L., Qi, R., Yang, M., 2011. Comparison of bacterial community structures in two systems of a sewage treatment plant using PCR-DGGE analysis. J. Environ. Sci. 23, 2049-2054.

Jin, B., Wilén, B.M., Lant, P., 2004. Impacts of morphological, physical and chemical properties of sludge flocs on dewaterability of activated sludge. Chem. Eng. J. 98, $115-126$.

Juretschko, S., Loy, A., Lehner, A., Wanger, M., 2002. The microbial community composition of a nitrifying-denitrifying activated sludge from an industrial sewage treatment plant analyzed by the full-cycle rRNA approach. System. Appl. Microbiol. 25, 84-99.

Kishida, N., Kim, J., Tsuneda, S., Sudo, R., 2006. Anaerobic/oxic/anoxic granular sludge process as an effective nutrient removal process utilizing denitrifying polyphosphate-accumulating organisms. Water Res. 40, 2303-2310.

Li, J., Bishop, P.L., 2002. In situ identification of azo dye inhibition effects on nitrifying biofilms using microelectrodes. Water Sci. Technol. 46, 207-215.

Li, B., Bishop, P.L., 2003. Modeling of the microenvironment of activated sludge floc with experimental and theoretical methods. J. Environ. Eng. Sci. 2, 27-37.

Li, B., Bishop, P.L., 2004. Microprofiles of activated sludge floc determined using microelectrodes. Water Res. 38, 1248-1258.

Martins, A.M.P., Picioreanu, C., Heijnen, J.J., Loosdrecht, M.C.M.V., 2004. Threedimensional dual-morphotype species modeling of activated sludge flocs. Environ. Sci. Technol. 38, 5632-5641.

Nadarajah, N., Allena, D.G., Roberta, R., Fulthorpe, R.R., 2007. Effects of transient temperature conditions on the divergence of activated sludge bacterial community structure and function. Water Res. 41, 2563-2571.

Pholchan, M.K., Baptista, J.D.C., Davenport, R.J., Curtis, T.P., 2010. Systematic study of the effect of operating variables on reactor performance and microbial diversity in laboratory-scale activated sludge reactors. Water Res. 44, 1341-1352.

Satoh, H., Okabe, S., Yamaguchi, Y., Watanabe, Y., 2003. Evaluation of the impact of bioaugmentation and biostimulation by in situ hybridization and microelectrode. Water Res. 37, 2206-2216.

Schmid, M., Thill, A., Purkhold, U., Walcher, M., Bottero, J.Y., Ginestet, P., Nielsen, P.H., Wuertz, S., Michael Wagner, M., 2003. Characterization of activated sludge flocs by confocal laser scanning microscopy and image analysis. Water Res. 37, 2043-2052.

Schramm, A., de Beer, D., van den Heuvel, J.C., Ottengraf, S., Amann, R., 1999. Microscale distribution of populations and activities of Nitrosospira and Nitrospira spp. along a macroscale gradient in a nitrifying bioreactor: quantification by in situ hybridization and the use of microsensors. Appl. Environ. Microbiol. 65, 3690-3696.

Shanahan, J.W., Semmens, M.J., 2006. Influence of a nitrifying biofilm on local oxygen fluxes across a micro-porous flat sheet membrane. J. Membr. Sci. 277 65-74.

Takacs, I., Fleit, F., 1995. Modeling of the micromorphology of the activated sludge floc: low DO, low F/M bulking. Water Sci. Technol. 31, 235-243.

Tsai, D.G., Lee, D.J., Lai, J.Y., 2008. Oxygen diffusion in single sludge floc. Adv. Powder Technol. 19, 475-481.

Vicente, A.A., Dluhy, M., Ferreira, E.C., Mota, M., Teixeira, J.A., 1998. Mass transfer properties of glucose and $\mathrm{O}_{2}$ in Saccharomyces cerevisiae flocs. Biochem. Eng. J. 2, 35-43.

Wang, L., Lv, Y.T., Wang, X.D., Yang, Y.Z., Bai, X.R., 2011. Micro-analysis of nitrogen transport and conversion inside activated sludge flocs using microelectrodes. Front. Environ. Sci. Eng. China 5, 633-638.

Wagner, M., Amann, R., Lemmer, H., Schleifer, K.H., 1993. Probing activated sludge with oligonucleotides specific for proteobacteria: inadequacy of culturedependent methods for describing microbial community structure. Appl. Environ. Microbiol. 59, 1520-1525.

Wells, G.F., Park, H.D., Eggleston, B., Francis, C.A., Craig, S., CriddleC, S., 2011. Finescale bacterial community dynamics and the taxaetime relationship within a full-scale activated sludge bioreactor. Water Res. 45, 5476-5488.

Yu, T., Bishop, P.L., 2001. Stratification and redox potential change in an aerobic and sulfate-reducing biofilm studied using microelectrodes. Water Environ. Res. 73, 368-373.

Zeng, W., Li, L., Yang, Y.Y., Wang, S.Y., Peng, Y.Z., 2010. Nitritation and denitritation of domestic wastewater using a continuous anaerobic-anoxic-aerobic (A2O) process at ambient temperatures. Bioresour. Technol. 101, 8074-8082. 